Article

\title{
Antisemitism and Jewish Children and Youth in Australia's Capital Territory Schools
}

\author{
Danny Ben-Moshe * and Anna Halafoff \\ Centre for Citizenship and Globalisation, School of Humanities and Social Sciences, Deakin University, \\ Melbourne Burwood Campus, 221 Burwood Highway, Burwood, VIC 3125, Australia; E-Mails: danny.bm@deakin.edu.au \\ (D.B.-M.), anna.halafoff@deakin.edu.au (A.H.); Tel.: +61-3-92446917 (D.B.-M.); Fax: +61-3-92446893 (D.B.-M.) \\ * Corresponding author
}

Submitted: 29 January 2014 | In Revised Form: 9 June 2014| Accepted: 11 June 2014 | Published: 20 August 2014

\begin{abstract}
Issues pertaining to religion and Australian schools have generated a significant amount of controversy and scholarly attention in recent years, and much of the attention in the religion and schools debate has focused on Muslim and nonreligious children's experiences (Erebus International, 2006; Halafoff, 2013). This article, by contrast, explores the manifestations of antisemitism as experienced by Jewish children and youth in Canberra schools. It considers the characteristics of antisemitism; when and why it occurs; its impact on the Jewish children and young people; and also the responses to it by them, the schools and the Jewish community. Based on focus groups with the Jewish students and their parents, the study reveals that antisemitism is common in Canberra schools, as almost all Jewish children and youth in this study have experienced it. The findings from this study suggest that there is a need for more anti-racism education. Specifically there is an urgent need for educational intervention about antisemitism, alongside education about religions and beliefs in general, to counter antisemitism more effectively and religious discrimination more broadly in Australian schools.
\end{abstract}

\section{Keywords}

anti-racism; anti-Semitism; Australia; children; education; interfaith; Jewish; religion; schools; social inclusion; youth

\section{Issue}

This article is part of the special issue "Migrant Youth, Intercultural Relations and the Challenges of Social Inclusion", edited by Professor Fethi Mansouri (Deakin University, Australia) and Dr. Anna Halafoff (Deakin University, Australia).

(C) 2014 by the authors; licensee Cogitatio (Lisbon, Portugal). This article is licensed under a Creative Commons Attribution 4.0 International License (CC BY).

\section{Introduction}

The special edition of this Journal explores theories of cultural diversity and multiculturalism in globalised cities, applied to migrant youth in particular. This article considers these issues in the context of the experiences of intercultural relations and social inclusion of Jewish children and youth at schools in the city of Canberra in the Australian Capital Territory (ACT). The article specifically explores varied experiences of everyday antisemitism among Jewish youth and the reported responses to such incidents by individuals, schools and communities.
2. Schools, Intercultural Relations, Social Inclusion and Antisemitism

As émigré countries, such as Australia, are shifting from being majority Christian to increasingly religiously (including no-religion) diverse societies (Halafoff, 2010), this has resulted in a re-thinking of the place of religion in the late modern public sphere and of what constitutes a secular society. These developments have led scholars to devise new frameworks for managing (Bouma, 1995; Bouma, 1999) or governing (Bader, 2007) religious diversity and to a series of debates centred on a number of controversial issues including the appro- 
priate relationship of religions to government institutions, including state schools.

Culturally, linguistically and religiously diverse (CRALD) communities, and Australian scholars, have made numerous requests for education about religions and beliefs (ERB) to be included in government schools from Kindergarten to Year 12 (Bouma, Pickering, Halafoff, \& Dellal, 2007, pp. 78-79; Lentini, Halafoff, \& Ogru, 2009, p. 7; Bouma, Cahill, Dellal, \& Zwartz, 2011, pp. 58-59, 80). Australia's government schools, however, are yet to provide comprehensive ERB programs to their students, other than in Year 11 and Year 12, despite the fact that educational programs about diverse religions have long been taught in the UK, Scandinavia and, more recently in Québec schools (Russell, 1974; MELS, 2005; Halafoff, 2012). In contrast, some Australian faith-based schools, particularly Catholic and Islamic schools, have been praised for conducting programs to promote religious literacy and interreligious understanding among diverse faith communities (Erebus International, 2006, pp. vi-vii; Bouma et al., 2007, p. 79). Indeed, following calls for Ethics education to be included in New South Wales and Victoria in 2009, broad based support has been growing for a more inclusive model of diverse worldviews (including religious and non-religious perspectives) education, taught by qualified educators, within the new National Curriculum (Halafoff, 2011, 2012).

The introduction of a National Curriculum is a highly significant development as Australian State governments have traditionally been responsible for education. Given that the "need to nurture an appreciation of and respect for social, cultural and religious diversity" has been highlighted within the "Melbourne Declaration on Educational Goals for Young Australians" (MCEECDYA, 2008, p. 4), the introduction of a National Curriculum creates an opportunity to review the way that Australian young people learn about religions at school. Optimistically, The Australian Curriculum, Assessment and Reporting Authority (ACARA), which is developing the new National Curriculum, has identified opportunities for teaching about diverse religions and beliefs in the Curriculum's learning areas of History and Civics and Citizenship, and in general capabilities and cross-curriculum priorities such as Intercultural Understanding and Ethical Behaviour. Yet, there is still a pressing need to develop appropriate resources and to provide adequate teacher education to enable the delivery of this cross-curriculum approach to religions and beliefs education for Australian schools (Halafoff, 2011, 2012).

Concerns have also been raised that exclusionary and divisive discourses, promoting Christian values over and above the values of other faith traditions, can undermine processes of social inclusion as they may lead young people from non-Christian communities to feel alienated from mainstream society. These types of discourses can also legitimise racial and religious vilification in host communities, as was the case in the 2005 riots at Cronulla beach in Sydney (Halafoff, 2006). Conversely, countering violent extremism (CVE) experts have argued that promoting religious literacy, interreligious understanding and affirming Australia as a multifaith, rather than an exclusively Christian, society is likely to minimise the risk of alienation and increase the sense of belonging among non-Christian youth and communities more generally (Halafoff, 2006; Halafoff \& Wright-Neville, 2009, pp. 924-927).

Despite recent calls for more research (Erebus International, 2006, pp. vii, 109; Cahill, Bouma, Dellal, \& Leahy, 2004, p. 126; Byrne, 2007, pp. 21, 74), a comprehensive study investigating existing levels of prejudice and religious and interreligious literacy among students in primary and secondary schools is yet to be conducted in Australia. Research into the efficacy of interreligious programs, in Australia, is currently slim and there is an urgent need for further scholarship in this field (Halafoff, 2010, p. 149). Moreover, as many interreligious educational programs have targeted immigrant communities, particularly Muslim communities in recent years (Erebus International, 2006, pp. xii-xiiii), it is important to assess whether it is indeed immigrant communities that are most in need of interreligious education, given that host communities have generated the bulk of the acts of discrimination and violence towards Australian Muslims (Lentini et al., 2009, p. 7) and possibly other religious minorities including Jews (Jones, 2012).

Focusing on this last group, manifestations of antisemitism in schools have become an issue of global concern for Jewish communities. According to a 2012 survey of over 5000 self-identifying Jews in eight EU Member States undertaken by the European Agency for Fundamental Rights, 66 per cent of respondents deemed antisemitism to be a problem, and 76 per cent felt the problem had got worse in their countries over the past five years (Bader, 2007). Indeed the problem has become so great in France that there has been a major spike in Jewish students being taken out of government schools and enrolled in private schools (Australian Jewish News, 2013, p. 21). In 2007 an OSCE-Yad Vashem joint report "Addressing Antisemitism", noted that antisemitism has recently come to the fore in educational settings. Based on an assessment of the OSCE Office for Democratic Institutions and Human Rights 2006 annual report on hate crimes in the OSCE region, the OSCE-Yad Vashem (2007, p. 3) report found that:

The number of attacks against Jewish schools increased in many countries while Jewish pupils were assaulted, harassed, and injured in growing numbers on their ways to and from school in the classroom, including by their classmates. Educators report that the term 'Jew' has become a popular swearword among youngsters. Rather than being confined to extremist circles, antisemitism is thus increasingly being mainstreamed. In this context, 
the conflict in the Middle East is often used as a justification for the expression of antisemitism at the very centre of society.

In terms of responding to antisemitism, the OSCE-Yad Vashem (2007, pp. 5-6) report noted that this is a multi-disciplinary task, which can be approached through many subjects such as civics education, literature, art, history and others, as either an entire course or a focussed lesson. The report stated that "regardless of the circumstance, a careful approach to the matter is important. Pedagogical methods should incorporate the need for both Holocaust education and for educational tools to raise awareness of anti-Semitism" (OSCE-Yad Vashem, 2007, p. 5). Antisemitism can also be approached as an example of racism and discrimination related to human rights in school curricula.

Specifically, the OSCE-Yad Vashem (2007, p. 14) report provided learning goals and methodological principles and strategies for teaching about antisemitism, noting that "responses to antisemitism tend to be particularly effective if teachers are familiar with the history of the Jewish people and anti-Semitism".

As this report shows, the management of religious diversity in schools must take place in the broader policy context of social inclusion. Developed by New Labour in in the UK in the 1990s, and subsequently adopted by multiple governments in Europe and elsewhere, including Australia in 2009, social inclusion has been defined in Australian policy as follows:

The Government defines an inclusive society as one in which every individual has the capabilities, opportunities and resources to participate in the economy and their community, taking responsibility for their own lives. (Department of the Prime Minister and Cabinet, 2010)

This article asks whether antisemitism, as a form of discrimination, undermines the social inclusion agenda; leading to the social exclusion of Jewish youth and their families?

\section{Antisemitism: Definitions and Manifestations in Australia}

There is no one absolute definition of antisemitism, but one widely accepted definition is offered by the Coordination Forum for Countering Antisemitism (CFCA, 2013):

Antisemitism is a certain perception of Jews, which may be expressed as hatred toward Jews. Rhetorical and physical manifestations of antisemitism are directed toward Jewish or non-Jewish individuals and/or their property, toward Jewish community institutions and religious facilities.
In addition, such manifestations could also target the state of Israel, conceived as a Jewish collectivity. Antisemitism frequently charges Jews with conspiring to harm humanity, and it is often used to blame Jews for 'why things go wrong'. It is expressed in speech, writing, visual forms and action, and employs sinister stereotypes and negative character traits.

Antisemitism is widely recognised as manifesting in different forms. These include: religious antisemitism which is the oldest type of antisemitism and is Christianbased but also existed in a pre-Christian pagan form; racial antisemitism in the form of Nazism which regards Jews as a race that is inherently inferior, evil and beyond salvation; and political antisemitism also known as the new-antisemitism or Judeophobia which is often manifest in the form of anti-Zionism with its double standards, demonization and delegitimisation of the State of Israel and which is widespread in the Arab and Islamic world and beyond (Cohn-Sherbok, 2002), although the claim that denial of Israel's legitimacy is antisemitic is not universally accepted (Klug, 2003). While these forms of antisemitism are different they all regard the Jews as collectively causing harm to non-Jewish people or states (Markus \& Taft, 2011).

A common characteristic to the different forms of antisemitism are various myths about Jews that have led to stereotypes, such as Jews are rich, tight with money and powerful. These images are negative in nature and thus reinforce prejudicial notions of Jews that are then manifest in the various forms of antisemitism. Antisemitism can take many forms including: stereotyping, social exclusion, physical assaults, written and verbal vilification, perpetuating myths, invoking ancient hatreds, accusing Jews of evil wrongdoing, denial of rights, including the right to self-determination in the national homeland Israel. For the purposes of this research, all these forms of antisemitism are considered.

Antisemitism was one of the areas of focus in the Gen08 study of Australian Jewry, which is the most comprehensive survey ever undertaken of the Australian Jewish community. According to a Gen08 report, "antisemitism is an issue of major concern for the Jewish community of Australia-as it has been since 1945, and before" (Markus \& Taft, 2011, p. 2). Of the Gen08 respondents 58 per cent stated that they had "personally experienced or witnessed antisemitism in Australia", the majority of these (71 per cent) were in the 1824 age group. Almost all of the young adults who participated in the Gen08 focus groups had encountered covert and overt antisemitism, with most cases being covert such as jokes involving Jewish stereotypes (Markus \& Taft, 2011, p. 3). While the Gen08 survey was comprehensive it included neither those under 18 nor those in the ACT, so the research in this paper extends the Gen08 findings to this cohort. 


\section{Canberra's Demography, Multiculturalism, and Its Jewish Community}

The Australian capital Canberra is home to around 347,000 people and rates highly on a range of measures maintained by the Australian Bureau of Statistics. In 2010 Canberrans had the highest rate of post-school qualifications and labour force participation in Australia, the longest life expectancy in the nation and the highest average weekly earnings ( $A B S$, n.d.). From this data it is clear that Canberra is a highly educated and prosperous community. This is important in understanding that the antisemitism discussed below is not arising from a community beset by social disadvantage.

Canberra is also a diverse community. Canberrans come from over 200 different countries, with approximately 22 per cent of the ACT population born overseas. Approximately 60 per cent of Canberrans identify as having a religious affiliation. In 2011, 7 per cent of ACT usual residents identified with a religion other than Christianity. The most common were Buddhism (2.6 per cent), Islam (2.1 per cent), and Hinduism (1.7 per cent). A further 29 per cent of ACT residents reported that they had no religion (ABS, 2013, p. 8).

In the 2011 census 776 ACT residents nominated their religion as Judaism (J-Wire, 2014). Most originate in other cities (Canberra Jewish Community, n.d.). One growth factor for the Canberra Jewish community is the steady arrival of Israeli immigrants. The Jewish community is dispersed across Canberra and Jewish children and youth attend a large and diverse number of government and private schools in the ACT (Ben-Moshe, 2011).

\section{The Research Sample, Questions and Findings}

The participants in the research upon which this article is based were students enrolled in the Jewish community's Sunday school program and their parents. The sample is not representative of the Jewish community, however the sample size constitutes a large percentage of Jewish children and young people in Canberra. Of the fourteen parents, six were Israeli, representing this new migrant population.

Focus groups were conducted on the morning of 6 November 2011 with the two Sunday school's oldest groups, years $2 / 3$ with the participation of 8 of the 9 enrolled pupils, and years 4- 6 with 8 of the 12 enrolled pupils. Their students attend a wide range of private, government, Catholic and Anglican schools during the week. The Jewish community wrote to all parents advising them of the research and encouraged them and their children to participate in the respective focus groups. Both focus groups had a mix of genders and lasted about an hour each. The School obtained consent from the parents of each child who participated in the focus groups. The focus groups were facilitated by their regular teacher to ensure the children were familiar with the person they were discussing this sensitive subject with.

Three qualifications need to be made about the sample. First, it is important to note that the participants are those who identity with and are actively involved in the Jewish community. How antisemitism affects those who do not identify remains unknown. Second, the oldest child to participate in the survey was 14 years old. Anecdotally several people mentioned that antisemitism becomes more of an issue for those in high school, particularly when it is more politically related to events to do with Israel but no empirical data was gathered to explore this in detail. Finally, there is also a Canberra Hebrew School group of Israeli children, but their schedule did not allow for participation in the research. Given that these children are more likely to look and sound Other, and be more directly connected to the Arab-Israeli conflict, it would be interesting to know about the nature and extent of their experience of antisemitism.

\subsection{Findings from the Children and Youth Focus Groups}

The focus group participants were asked a series of qualitative semi-structured questions about antisemitism, including if they had experienced antisemitism and if so, the frequency and nature of antisemitism that occurred i.e. verbal or physical attack, the place where the antisemitism took place e.g. classroom, playground, and their reactions to the antisemitism, how it made them feel and what, if anything, they did about it.

\subsubsection{The Extent and Experience of Antisemitism}

For the eight children aged 9-11 only two expressed what could be described as serious and ongoing vilification and victimisation at school, with one student saying "it's really bad, I don't know why they do it, it makes me feel bad".

While not every participant in both groups reported that they had experienced antisemitism, this fact did not mean fear of antisemitism was absent in their lives. This was evidenced by a telling comment from a 12-14 year old who said they had not experienced any antisemitism but they only told those they trusted that they were Jewish. Another student in this focus group similarly said there were no incidences of antisemitism they could think of, but when other students started to describe antisemitic encounters they had, they commented, "I went to assembly and some kids told me to sit in a particular seat and when I got there, there was a sign that said 'Jew' on it".

The majority of antisemitic incidents were of a verbal nature and confined to the school grounds. As such, several Jewish pupils did not take them too seriously and seemed to take them in their stride, so to speak, as part of the antics of the school environment. As one participant in the 12-14 year old focus group said, 
"They don't mean anything by calling you a Jew. It's like calling you gay. It's just something they say". This acceptance of everyday prejudice, against both Jews and homosexual people is, however, troubling.

The antisemitism which did occur reflected deepseated stereotypes of Jews, with several students confirming that they had comments directed at them like "don't be a Jew", as they were targeted with the invective of the Jewish obsession with money. Indeed, reference to Jews and money and the related envy about Jewish Bar and Bat-Mitzvahs (coming of age religious ceremonies that are also celebrated with parties) at the age of 12 for girls and 13 for boys, was very common. One child reported comments such as, "they threw down some money and I picked it up and they said I passed the Jew test".

In the worst antisemitic incident conveyed in the focus group, a student in the 12-14 year old cohort was repeatedly told that the Nazis were going to come and finish the job they had started. The student also explained how this was followed up by a swastika being drawn on their classroom wall. The recounting of this incident triggered another 12-14 year old to report leaving their classroom briefly and then returning to their desk to find a Swastika drawn on it. While these were the only two incidents relating to Nazi references amongst all fourteen focus group participants, the invoking of the Nazi imagery and its intimidating effect is a cause for serious concern.

\subsubsection{The Religious Dimension of Antisemitism}

The antisemitism that was described by the children and young people, in addition to being based on stereotypes about Jews and money, was frequently based on religious ignorance, insensitivity and intolerance. This came to fore in religious education issues in general and at Christmas time in particular.

One 9-11 year old participant described being at a party where they were offered pizza, which they declined because it had ham on, and the child whose party it was responded, "if you are Jewish it's stupid, be a Catholic". The Jewish child confided in the focus group "it made me feel upset. I haven't told anyone". Another 9-11 year old focus group participant reported another child saying, "why can't you tell your parents you don't want to be Jewish". This Jewish child explained in the focus group "it does get annoying being teased but I want to be Jewish". Several children told how they were asked why they didn't go to church. It is of course possible for questions about why Jews do not attend church to be asked out of genuine curiosity, but according to the focus group participants in their case they were asked with malicious intent. As such they were intended to make the Jewish child feel like an outsider who was unwelcome and did not fit in because they did not attend church.
This combination of ignorance, insensitivity and intolerance seems to be particularly pronounced at Christmas time, as many of the Jewish children reported being teased for not celebrating Christmas. Indicative comments were those relayed by a 9-11 year old who said he was told, "you are so unlucky you can't celebrate Christmas". The prejudice and ignorance of non-Jewish school children is reinforced by school policy. As one 9-11 year old put it, "we learn about Christmas but not Chanukah...why only Christmas? Christians are not the only religion in the world".

Christmas appears to be time of heightened anxiety for Jewish pupils, as several children from the 9-11 year old focus group reported non-Jewish children being "annoyed" at their Jewish peers for having an eight day holiday, Chanukah, around the time of Christmas. The same child from the 9-11 year old focus group quoted above also added: "They went on and on and it made me feel annoyed". Some of the Jewish pupils were clearly intimated by the nature and extent of questioning about why they did not celebrate Christmas and instead celebrated an eight day holiday.

The religious dimension of antisemitism, the ancient antisemitic canards about Jews killing Jesus, and denying his status as $\mathrm{G}-\mathrm{d}^{1}$, were also surprisingly common. Sometimes this was expressed in a hateful way and other times naively, with pupils simply asking "but Jesus is G-d so why don't you believe in him". The way this quote was shared in the focus group suggests the intent was not to be antisemitic, but the focus group participant who conveyed this experience made clear that it made them feel questioned, doubted and wrong, contributing to their sense of otherness and exclusion. The detrimental effect of this is compounded by the fact that, as is discussed below, the schools seem unaware or uninterested in their occurrence and impact.

Insensitivity and ignorance was manifest by both schools and their pupils in relation to Jewish religious and cultural needs, particularly dietary requirements. Indeed, the Jewish children found themselves to be constantly on the defensive explaining why they don't eat pork. For the most part such comments were based on curiosity by other children, but the insensitivity of schools on this issue made the Jewish pupils feel intimidated, constantly having to explain if not rationalise their behaviour; so while the intent may not have been antisemitic, by being forced to defend their religious practices these focus group participants felt the legitimacy of their practices were questioned rather than accepted. One child in the 9-11 year old focus group reported being on school camp where pork was being served. When he explained to the cook that he could not eat it and was asked why and he explained he was

\footnotetext{
1 Jews are prohibited for writing in full the name G-d, so the custom is to write it with a hyphen, or to use other terms such as "Yahweh".
} 
Jewish the cook said: "Well that's stupid. You should just eat it". Several students in the 12-14 year age group complained that there were halal and other options on school forms but not kosher.

\subsubsection{School Attitudes}

Significantly, religious ignorance, insensitivity and intolerance were expressed not only by pupils but also the schools themselves. What can be described as religious insensitivity at best, and outright discrimination and intimidation at worse, was manifest in several ways relating to religious studies. One student in the 12-14 year old focus group described a lesson where they had to write G-d's name so he wrote "YAHWEH" because Jews are forbidden to write the name of G-d in full. Their teacher asked why they could not write the word, and when the pupil explained that this was not permissible to Jews, the teacher told him to "just write it anyway". This pupil was thus forced by a school authority to engage in an act even though he made clear it was against his Jewish faith. Forcing a Jew to act in contravention to their beliefs is a long-term manifestation of antisemitism, and whatever its motives its impact and experience is often felt to be discriminatory.

The problem of disregarding Jewish religious rites was particularly pronounced in relation to attending chapel. One participant in the 12-14 year old group explained how they are forced to go to chapel and as the teacher knew they were Jewish they walked up and down the aisle close to the pupil to make sure they were participating in the service.

In another case, an Orthodox Jewish student refused to go to chapel at all because, according to Jewish law, it is forbidden to enter a church while Christian prayers are taking place. The school's reaction was to effectively punish the pupil by forcing them to sit in the detention room while chapel was taking place and the school worked out how to handle the situation. Only after the pupil's outraged parents threatened legal action was the child reluctantly given an exemption from chapel.

Not all schools, however, were ignorant, insensitive and intolerant to the needs of their Jewish students. Yet sometimes the efforts of schools to be inclusive, while well-intentioned, made matters worse. For example, several children reported being suddenly called on by their teachers during a class to offer a Jewish perspective, but the pupils found this troubling as they didn't feel confident about the subject matter or speaking about it before their peers. Furthermore, the Jewish students felt that while the teachers attempt to involve them was well-meaning, it felt patronizing in practice.

\subsubsection{Children's Responses}

Part of the problem in dealing with antisemitism in schools is that the Jewish children are not reporting it when it occurs to either their schools or their parents. This was the case for almost all the focus group participants. In relation to reporting incidents to schools one 9-11 year old despondently reflected, “I don't know how it would help". Another 9-11 year old expressed the dilemma of reporting, saying "sometimes teachers are nice and you get called a teacher's pet and kids start being mean to you".

The scenario of not telling parents about the antisemitic incidents is predicated on two factors. One, the ubiquitous feeling amongst the focus group participants that there is nothing the parents can do, and secondly that the parents reaction and subsequent intervention with the school will cause the child more problems. As one 9-11 year old surmised:

I didn't tell mum as she'll want to be make a big deal of it and I don't want to be embarrassed. I'm already not popular (at school) and I don't want to get into trouble and or get others in trouble. I feel it will get worse if I say something.

While there clearly were multiple individual incidents of antisemitism occurring in schools, there were no concerted antisemitic campaigns as such. It must also be noted that overall there was a high level of acceptance of the Jewish children, or in the words of a 911 year old, "all the people at my school don't mind me being Jewish".

While school administrators were generally not seen as being sympathetic to the needs of the Jewish students, some teachers were noted for being caring and concerned. Examples of such behaviour by teachers included intervening in playground incidents when antisemitic incidents occurred and checking if food being offered at the school was kosher.

Examples were also cited of some good practice in terms of religious and intercultural education. This was the case with a 9-11 year old who described how at the time when the school was engaged in Christmas celebrations the pupil took the initiative of sharing the Jewish Chanukah tradition of bringing in chocolate money for everyone to eat "and everyone liked it". When initiative is taken by the schools to enhance education and understanding about Judaism it can have a positive effect. This was evidenced by a 12-14 year old who stated that "my teacher made me talk about Judaism (in religious education) and my class seemed interested". One 9-11 year old also described how their class watched a film about Anne Frank and afterwards "all my friends hugged me and I asked why and they said it could have been you".

\subsection{The Parental Focus Group}

The parents of the Senior and Youth classes were invited to participate in a focus group about antisemitism as ex- 
perienced by children in Canberra. The School predicted that "about six" parents may participate. However, fourteen chose to do so; this high level of participation is indicative of the concern about antisemitism that these parents expressed in the focus group itself. The parents inevitably had a more sophisticated understanding than their children about the forms antisemitism can take and the negative impact it can have. The focus group lasted for an hour and a half and also took place in the Sunday school on 6 November 2011. There were seven men and seven women in the focus group. Of the participants, three were married couples.

There was a strong sense amongst all the parents that their children were exposed to antisemitism at school. The parents' concern was understandably about the impact this had on their children. One parent said they had "no doubt their child was affected" and the fact that their child did not discuss it with them confirmed for them that their child had an issue of concern they were hiding from them. While the parents mostly recognised that their children could navigate the antisemitism in schools, they expressed concern that their children felt they had to hide or downplay their Jewish identity.

Concomitantly, there was genuine and widespread concern about their children being excluded because they were Jewish, although they noted that while they were excluded from some social groups in the school they were welcomed into others. Parents also stated that the sense of isolation children felt was more pronounced at Christmas time, which reinforced the religious ignorance and intolerance discussed above.

It is clear that ignorance, rather than malice, is often the cause of discrimination and social exclusion felt by the Jewish school children. Perhaps the most glaring example of a comment meant in a positive way, yet which was an expression of classical antisemitism, was conveyed by a parent who described how when their child arrived at their new school the teacher welcomed them by stating:

Just like Germans killed Jews in the Holocaust and you don't blame today's Germans, although Jews killed Jesus we don't blame you.

While physical incidents of antisemitic abuse only occurred on one occasion, there was a general feeling that the overall environment was unsafe and, unless something was done about it, verbal abuse could degenerate into physical violence.

Parents also reported antisemitic incidents tied in with the Israeli-Palestine conflict, and as such were manifestations of "new antisemitism". The parent of a high school student said her child is often confronted about "Israeli oppression of the Palestinians and it's hard for her to deal with that". Another participant reported the physical assault of their nephew in a school incident with a Muslim child in connection to the Middle East conflict. Unlike secondary school, there was no evidence of the new antisemitism in primary school. This suggests that this additional form of antisemitism may occur as the youth become more politically conscious in their secondary school years.

The parents themselves admitted to not knowing how best to respond to the antisemitism. Acknowledging that some schools and teachers tried to engage the Jewish students on Jewish subject matter, parents generally felt it was neither right nor fair to place this onus on Jewish children to play a role in educating their peers and the school about Judaism. They also appreciated that their children did not want them to get involved in trying to fix their problems. This only added to distress experienced by parents concerned about their children experiencing antisemitism.

\section{Analysis and Discussion}

A number of key themes and findings emerge from this research. Paradoxically, the social inclusion and social exclusion of Jewish students is occurring simultaneously in Canberra. As a result of malicious antisemitism and unknowingly offensive myths and stereotypes Jewish youth were experiencing social exclusion. The psychological impact of suddenly being excluded from a community from which these students thought they were an accepted part should not be underestimated. Simultaneously there is a proactive process of social inclusion occurring in response to this social exclusion, initiated by the children and young people themselves, and by some teachers and schools.

The most common form of antisemitism that occurred was faith-based and as such was often expressed in the articulation of ancient stereotypes that in many instances were negative in nature. Founded on and manifested through insensitivity, ignorance and intolerance on the part of pupils, teachers and schools, this was especially pronounced at Christmas time, which is a particularly stressful time for Jewish children attending school in Canberra. The Territory's schools, while nominally pursuing multiculturalism, are insensitive to the religious and cultural needs of the Jewish pupils.

Age-old negative stereotypes about Jews remain deeply entrenched in the mindset of primary and middle school year children in Canberra and are being expressed freely and regularly to the small number of Jewish children attending Canberra schools. Consequently, there was a disturbingly resigned acceptance by the children that antisemitism happens and you just put up with it.

Importantly, even though all the Jewish children who participated in the focus group experienced antisemitism in schools, they all had many non-Jewish friends who rejected antisemitism and facilitated social inclusion. This was a factor that they all found heartening. 
The fact that the Jewish community in Canberra is small in number, with the children often being the only Jewish child in their year level or school, meant the onus was on them to represent Judaism, and many did so with pride. Examples included standing up in class to explain a Jewish festival, wearing a Star of David around their neck or in one case, a boy boldly walking into school wearing a skull cap. The Jewish identity of these children appeared to be stronger as a response to the antisemitism. Conversely, some Jewish children and young people did not feel comfortable about publicly having to explain or display their faith and culture. Nor did their parents think it should be up to them to educate the school community about Judaism.

Clearly the impact of the antisemitism on the children and how they deal with it varies considerably according to each student's disposition. Some children and youth are more vulnerable than others. While bulling is clearly a concern for all children who are its victims, antisemitism adds another layer of impact to Jewish children being bullied.

The distress experienced by the children placed a stress on their parents who struggled to find the means to address this problem. Virtually all of the children declined to report on the antisemitism to either their schools or their parents. There was unanimity amongst all the children that this would be a bad idea because the school wouldn't understand or do anything about it, their parents would get involved and that would be "embarrassing" and make the situation worse.

The research also reflects how children's experiences can negatively impact on the social inclusion of parents. The focus group discussion with the parents of Jewish school children reveals that the social exclusion and antisemitism experienced by their children heightens their own sense of being outsiders, which is particularly pronounced for recent Israeli migrants. This is compounded when their own interventions with school the school authorities are unsuccessful. While the law provides some protection for Jewish parents and their children, in practical terms it is not a viable option for many parents to pursue legal recourse. While one parent in the focus group did pursue anti-discrimination legal action, they worked in law so had the skill set and means to do so.

It is clear given the problem of antisemitic social exclusion outlined in this article that proactive measures are required for intercultural relations and social inclusion to be advanced in Canberra schools. There is an urgent need for all schools, primary and secondary, and government and private, to take steps to prevent and handle manifestations of intended and unintended antisemitism. This needs to include the entire school community of pupils, teachers and administrators.

In particular, there is an enhanced need for diversity training and education about Jewish beliefs and practices. Teacher education about Judaism is clearly required. How teachers understand and deal with issues of cultural diversity is something that must be addressed through teacher education so that the teacher is equipped once they are in the classroom.

There is also a need for school administrators and teachers to be aware not only of Jewish cultural practices, for example in relation to going to chapel, but also their legal rights on these matters. Moreover, schools also need to urgently review and establish their policies for handling complaints of antisemitism. They may wish to consider, for example, having a system of referral to the Jewish community or one of its agencies and partnerships that could be operational in these situations. There is no doubt that the development of such polices and practice, and overcoming the problem of antisemitism in the school sector, will benefit from schools engaging with the Jewish community. Given the strong Christian dimension to the expressions of antisemitism, and the Christian faith-based nature of several schools that Jewish children attend in Canberra, addressing the problem of antisemitism in schools will also be advanced by the wider Church leadership being involved in partnerships with the Jewish community.

Finally, this article illustrates how racism, discrimination and stereotyping contribute to social exclusion. This clearly undermines intercultural relations and suggests that further advances in multiculturalism are required if social inclusion is to be experienced by youth in Canberra schools. This will entail addressing frameworks for managing and governing religious diversity in schools including education about diverse religions and beliefs in general, and education about non-Christian communities in particular.

\section{Conclusion}

The findings reported in this article suggest that the experience of Jewish pupils at school in Canberra is similar to that experienced by the much wider sample from the Gen08 study (Markus \& Taft, 2011), with significant covert antisemitism such as stereotyping jokes being common. Indeed, as with the data collected for the Executive Council of Australian Jewry Antisemitism Annual Report (Cohn-Sherbok, 2002), this hatred is more manifest in verbal and written form rather than violent attacks. The incidents directed at Jewish children that are occurring in Canberra clearly fall within the internationally accepted definitions of antisemitism. While the scale may appear slight, the impact on the victims and the community is significant. It contributes to high degrees of social exclusion of the Jewish students, and the schools are failing to appreciate the nature and impact of this antisemitism. Furthermore, the schools while nominally pursuing multiculturalism are insensitive to the religious and cultural needs of the Jewish pupils.

The research findings presented in this article indi- 
cate that cultural diversity is not deeply entrenched as a lived experienced in Canberra. The nature of the ACT community, with high levels of education and employment, makes surprise and concern about the antisemitism all the more pronounced.

Antisemitism in schools cannot be considered in isolation and schools cannot fix this problem in isolation. An all of community approach is required if this problem is to be overcome, with the schools working actively with Jewish communities, Christian communities and other religious communities and interfaith organisations in their area.

School policy and procedure for dealing with this issue is required as a matter of urgency. In its absence, Jewish children are being socially excluded for no other reason other than the fact that they are Jewish. A coherent schools strategy is required to address this, as opposed to current ad hoc measures.

There are, however, several reasons for optimism. While some children confront the antisemitism, other non-Jewish children find the antisemitism offensive and include the Jewish children as their friends. Further, since much of the antisemitism reported in the study is based on ignorance rather than hatred means it can be addressed through education.

Given religions' ambivalent roles in creating and ameliorating social problems (Beckford, 1990; Appleby, $2000)$, it is the responsibility of the state to guard against exclusive religious narratives, and religious vilification, including antisemitism, which are capable of perpetuating prejudices and inspiring conflicts. It is also vital that no one religion should be given a privileged status within a government education system, instead, a critical education about diverse religions and beliefs can assist in advancing cosmopolitan principles, such as advancing equal rights and respect for diversity and common law, and thereby enable processes of social inclusion and countering extremism within school communities and in broader society (Halafoff, 2010, pp. 41-42). The new National Curriculum provides an opportunity to address these issues.

\section{Conflict of Interests}

The authors declare no conflict of interests.

\section{References}

Appleby, R. S. (2000). The Ambivalence of the Sacred: Religion, Violence, and Reconciliation. Maryland, USA: Rowman and Littlefield Publishers.

Australian Bureau of Statistics (ABS). (n.d.). Australian Capital Territory Statistical Indicators. Retrieved from http://www.abs.gov.au/websitedbs/D3310114. nsf/home/home?opendocument\#from-banner=GT

Australian Bureau of Statistics (ABS). (2013). 4102.0Australian Social Trends. April 2013. Common- wealth of Australia. Retrieved from http://www. abs.gov.au/AUSSTATS/abs@.nsf/Lookup/4102.0Mai n+Features50April+2013

Australian Jewish News. (2013). Fear of anti-Semitism forces French kids to Jewish schools. 6 December 2013, p. 21.

Bader, V. (2007). Secularism or Democracy? Associational Governance of Religious Diversity. Amsterdam, Netherlands: Amsterdam University Press.

Beckford, J. A. (1990). The sociology of religion and social problems. Sociological Analysis, 51(1), 1-14.

Ben-Moshe, D. (2011). Interview with President of the Australian Capital Territory Jewish Community, Kim Rubenstein. 20 November 2011.

Bouma, G. D. (1995). The emergence of religious plurality in Australia: A multicultural society. Sociology of Religion, 56(4), 285-302.

Bouma, G. D. (1999). From Hegemony to Pluralism: Managing Religious Diversity in Modernity and Post-Modernity. In G. D. Bouma (Ed.), Managing Religious Diversity: From Threat to Promise (pp. 727). Melbourne, Australia: Australian Association for the Study of Religions.

Bouma, G. D., Cahill, D., Dellal, H., \& Zwartz, A. (2011). Freedom of Religion and Belief in $21^{\text {st }}$ Century Australia. Canberra, Australia: Australian Human Rights Commission.

Bouma, G. D., Pickering, S., Halafoff, A., \& Dellal, H. (2007). Managing the Impact of Global Crisis Events on Community Relations in Multicultural Australia. Brisbane, Australia: Multicultural Affairs Queensland.

Byrne, C. (2007). Spirit in the 'Expanding Circle'. Why Learn About Religion in Australia in the 21st Century? Can Comparative Religion Knowledge Enable Cultural Diversity Capacity? Masters Thesis. Australia: University of Queensland.

Cahill, D., Bouma, G. D., Dellal, H., \& Leahy, M. (2004). Religion, Cultural Diversity and Safeguarding Australia. Canberra: Department of Immigration, Multiculturalism and Indigenous Affairs.

Canberra Jewish Community. (n.d.). Retrieved from: http://www.canberrajewishcommunity.org

CFCA. (2013). Working Definition of Antisemitism. Coordination Forum for Countering Antisemitism. Retrieved from http://www.antisemitism.org.il/eng/ Working\%20Definition\%20of\%20Antisemitism

Cohn-Sherbok, D. (2002). Antisemitism. UK: Sutton Publishing.

Department of Housing, Disability, and Community Services. (2013). Multicultural Strategy 2010-2013. Retrieved from http://www.communityservices. act.gov.au/_data/assets/pdf_file/0010/104689/Fi nal_ACT_Multicultural_Strategy_2010_-2013_25_ Nov.pdf

Department of the Prime Minister and Cabinet. (2010). Social Inclusion Policy. Retrieved from www.dpmc. 
gov.au/annual_reports/2009-10/html/special-featu res/social-inclusion-policy

Erebus International. (2006). Encouraging Tolerance and Social Cohesion through School Education. Canberra, Australia: Department of Education, Science and Training.

Halafoff, A. (2006). UnAustralian Values. In Proceedings from UNAUSTRALIA Conference 2006. Canberra, Australia: University of Canberra.

Halafoff, A. (2010). Netpeace: The Multifaith Movement and Common Security. PhD Thesis. Australia: Monash University.

Halafoff, A. (2011). Addressing the problem of Special Religious Instruction (SRI). ABC Religion and Ethics Blog. 28 May 2011. Retrieved from www.abc.net. au/religion/articles/2011/05/28/3229553.htm?topi c1=\&topic $2=$

Halafoff, A. (2012). Time for change: A new role for religion in education. The Conversation. Retrieved from theconversation.edu.au/time-for-change-anew-role-for-religion-in-education-6564

Halafoff, A. (2013). Education about religions and beliefs in Victoria. Journal for the Academic Study of Religion, 26(2), 172-197.

Halafoff, A., \& Wright-Neville, D. (2009). A missing peace? The role of religious actors in countering terrorism. Studies of Conflict and Terrorism. 32(11), 921-932.

Jones, J. (2012). Report on Antisemitism in Australia 2000-2011. Retrieved from http://www.ecaj.org. au/wp-content/uploads/2012/08/2011_antisemi tism_report.pdf

J-Wire. (2014). Jewish Online News from Australia, New Zealand and world-wide web. 2011 Census
Jewish Facts and Figures. Retrieved from http:// www.jwire.com.au/news/2011-census-jewish-factsand-figures $/ 42646$

Klug, B. (2003). No, anti-Zionism is not Antisemitism. The Guardian. Retrieved from http://www.the guardian.com/world/2003/dec/03/comment

Lentini, P., Halafoff, A., \& Ogru, E. (2009). Perceptions of Multiculturalism and Security in Victoria: Report to the Department of Premier and Cabinet, State Government of Victoria. Melbourne, Australia: Global Terrorism Research Centre, Monash University.

Markus, A., \& Taft, J. (2011). Report Series on the Gen08 Survey: Antisemitism. Retrieved from: artsonline.monash.edu.au/gen08/files/2012/12/gen08 -report4-antisemitism.pdf

MCEECDYA. (2008). Melbourne Declaration on Educational Goals for Young Australians. Melbourne, Australia: Ministerial Council on Education, Employment, Training and Youth Affairs.

Ministère de l'Éducation, du Loisir et du Sport (MELS). (2005). Establishment of an Ethics and Religious Culture Program: Providing Future Direction for all Québec Youth. Québec City: Government of Québec. Retrieved from www.mels.gouv.qc.ca/lance ment/Prog_ethique_cult_reli/prog_ethique_cult_re li_a.pdf

OSCE-Yad Vashem. (2007). Addressing Antisemitism: Why and How? A Guide for Educators. Organization for Security and Co-operation in Europe. Retrieved from: www.osce.org/odihr/29890

Russell, H. B. (1974). Religious Education in Schools. Victoria, Australia: Committee on Religious Education.

\section{About the Authors}

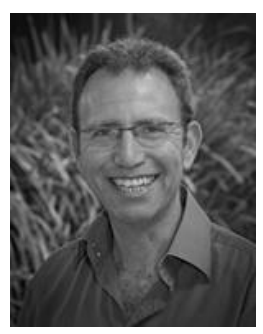

Dr. Danny Ben-Moshe

Associate Professor Danny Ben-Moshe is a Principal Research Fellow at the Centre for Citizenship and Globalisation at Deakin University in Melbourne. He is the coeditor of the book Israel, the Diaspora and Identity (Sussex 2008) and he is a documentary filmmaker at www.identity-films.com.

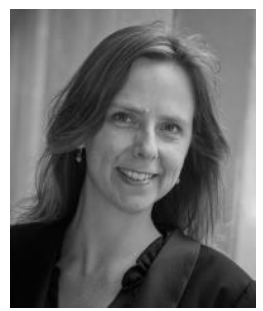

Dr. Anna Halafoff

Dr. Anna Halafoff is a Lecturer in Sociology, and a member of the Centre for Citizenship and Globalisation, at Deakin University. She is also an Associate of the UNESCO Chair in Interreligious and Intercultural Relations-Asia Pacific, at Monash University. Dr Halafoff's current and recent research projects/interests include: intercultural and interreligious relations; education about religions and beliefs; and Buddhism in Australia. Anna was named a United Nations Alliance of Civilizations' Global Expert in the fields of multifaith relations, and religion and peacebuilding in 2011. 